\title{
Nullidade das doações á concubina
}

\author{
Alvino Lima
}

Em facc dos dispositivos expressos dos artigos $248 \mathrm{n}$. IV e 1177 do Codigo Civil, nullas são as doações feitas pelo marido á sua concubina ou do conjuge adultero ao seu cumplice.

Mas, em se tratando de bens immoveis, a doação feita á concubina é nulla pela falta de outorga uxoria, nos termos do cit. art. 248 n..$^{\circ}$ II do citado Codigo. Desnecessaria seria, pois, a referencia feita pelo legislador, no art. 248 n. IV, á nullidade das doações de bens immoveis á concubina, porquanto a hypothese ficára prevista no dispositivo do n. II do mesmo artigo.

Entretanto, parece-nos, que o facto de ter o legislador declarado, expressamente, no art. 1177 cit., que a mulher pode annullar a doação do conjuge adultero ao seu cumplice, reportando-se ao dispositivo do art. $248 \mathrm{n}$. IV, creou uma hypothese diversa que autoriza a annullação da doação, ainda que a mulher tenha outorgado o seu consentimento.

A these, pois, que constitue objecto do presente estudo, é a seguinte: - Pode a mulher annullar a doação feita á concubina de seu marido, mesmo que tenha consentido?

Commentando o dispositivo do art. 1177 cit., Carvalho Santos ("Codigo Civil Brasileiro Interpretado", vol. 16, pag. 419), com apoio em Cunha Gonçalves e Dias Ferreira, declara que a mulher não pode annullar a doação á concubina, uma vez que tenha concordado expressamente, por não se tratar de uma nullidade de ordem publica. 
A nós se nos afigura que a nullidade é substancial, por se tratar de materia de interesse publico, podendo a mulher annullar a doação e reivindicar os bens doados.

Varias são as razões juridicas que justificam a nossa asserção:

a) Nos termos do art. 82 do Codigo Civil, a validade do acto juridico depende de ser licito o seu objecto, sob pena de nullidade, nos termos do art. $145 \mathrm{n}$. II do cit. Codigo. A expressão "objecto" não é tomada sómente no sentido restricto de cousa material, mas no sentido amplo, abrangendo os motivos da prestação ou do acto; o objecto illicito encerra tambem o que é contrario aos bons costumes (vide C. SAntos, obr. cit., vol. III, pag. 236; Espinola, "Factos Juridicos”, ed. P. Lacerda, vol. II,, parte IV, pag. 474).

Não é necessario fixar o conceito do que seja - bons costumes -, nem entrar em divagações theoricas sobre a materia, que tanto se presta ao torneio das doutrinas (vide a respeito a obra de Zeno Oprea - "Essai sur la notion de bonnes moeurs dans les obligations en droit civil allemand"), para se affirmar que a doação á concubina fére os bons costumes, e, consequentemente, encerra um objecto illicito.

Mas, ao affirmar que o objecto é illicito, quando o são os motivos da prestação ou do acto, esbarramos na objecção dos defensores da theoria classica da causa:

A causa nas doações puras é tão sómente o desejo de praticar uma liberalidade; ora, tal desejo não pode ser immoral, e, consequentemente, impossivel seria annullar uma doação sob o fundamento de ser illicito o seu objecto (vide Capitant, "De la cause dans les obligations", n. 34).

A theoria classica da causa cede, entretanto, o seu posto, no direito civil moderno, á theoria da causa impulsiva e determinante, na qual os motivos particulares individuaes e adventicios, determinativos do acto juridico, são tomados em consideração (vide Josserand "Les mobiles dans les actes juridiques de droit privé”, ns. 123 e seguintes). 
Foi, sob a influencia desta nova doutrina, que a jurisprudencia francesa, na ausencia de um texto expresso prohibitivo das doações á concubina, fixou a nullidade de taes doações, em virtude de sua causa illicita (vide BonNEcase "Supplement" ao "Tr. de droit civ." de Baudry, vol. II, ns. 564 e segs.; Pierre Guinard "Les effects juridiques de l'union libre en jurisprudence", n. 24). Mesmo, porém, que se defenda, como expressão da verdade juridica, a theoria classica da causa, como o faz JeAn Dabin ("La theorie de la cause", n. 263), collocando a questão sob o terreno da convenção illicita, tendo, ao lado da causa-intenção liberal, outra, que é a illicitude (BuFNoIr), a doação á concubina é nulla, por ser illicito o seu objecto.

A despeito da opinião em contrario e valiosa de Ferrara ("Teoria del negozio illecito", 2. ${ }^{a}$ ed., n. 81), a doutrina dominante condemna como immoral a doação á concubina (vide Planiol-Rippert-Trasbot. "Donations et Testaments", n. 266; - Adolpho Cotrino, "Le Donazioni", n. 10; - Rippert, "La régle morale dans les obligations civiles", n. 25).

b) O preceito prohibitivo das doações á concubina não visa tão sómente o interesse privado; é, sem duvida, preceito de ordem publica.

Não é possivel, como confessa Lienhard ("Le rôle et la valeur de l'ordre public"), dar um conceito preciso de leis de ordem publica, nem fixar sua classificação; o melhor criterio é determinal-as ou classifical-as em cada um dos ramos do direito.

Entretanto, é verdade incontestavel, que os preceitos juridicos protectores da organisação e da estabilidade da familia não interessam sómente aos particulares, mas affectam o interesse publico, a propria organisação social.

O casamento, como associação conjugal, visa um fim essencial, que ultrapassa os proprios conjuges; os dispositivos legaes que impõem aos conjuges deveres e obrigações não podem ser derrogados pela vontade individual. Uns, visando a propria estabilidade da familia, affectam a associação 
dos bens do casal, prohibindo a sua disposição a arbitrio pessoal de qualquer dos conjuges. Dentre estes, quer pela sua significação economica, em face da familia legal, quer pelo seu aspecto moral, avulta, justamente, a prohibição das doações á concubina. Prohibir a delapidação deste patrimonio, tanto quanto possivel, é proteger a permanencia da familia, garantir a sua estabilidade, satisfazer seus fins, protegendo, portanto, um dos maximos interesses de ordem publica. Mas não é só visando o lado patrimonial que aquella prohibição legal acautela um interesse de ordem publica. O lado moral é, sem duvida, preponderante.

A prohibição legal é uma condemnação formal á união livre; visa proteger a familia legal annullando todos os actos que favoreçam a familia illegal, de maneira a não permittir que se pague "o salario dos vicios" (vide Henri Simonnet "Le mariage et l'union libre", conferencia publicada no volume "Le maintien et la défense de la famile par le droit" Rec. Sirey - 1930).

Ora, se o motivo preciso do caracter imperativo de uma regra juridica constitue, na lição LiENHARD, o criterio para se determinar se ha um interesse de ordem publica, não ha negar-se que a prohibição das doações ás concunbinas não visa sómente o interesse privado, mas tambem o interesse publico.

E' de se ponderar que, desviando desta forma o patrimonio da familia legitima para a illegitima, são prejudicados os filhos legitimos em proveito dos illegitimos, que passarão a ser, na realidade, verdadeiros herdeiros, com manifesta fraude á lei. A condição preliminar da sanç̧ão da fraude á lei consiste em attingir resultados equivalentes aos que a lei proscreveu (vide Alexandre ligeropoulo, "Le problème de la fraude à la loi", n. 42).

A doação á concubina, maximé quando na mesma se estipula a favor da concubina o usofructo, pertencendo a propriedade aos seus filhos, é um reconhecimento indirecto de filhos adulterinos, aos quaes se confere, fraudulentamente, uma verdadeira successão aos bens do pae illegitimo. 
Do exposto concluimos que as doações á concubina não só contêm um objecto illicito, como a sua prohibição encerra um preceito de ordem publica.

Nullas são, consequentemente, as doações á concubina, ainda que a mulher tenha dado sua outorga, nos termos dos artigos 82 e 145 do Codigo Civil, pois a outorga uxoria não expurga o acto de seu vicio de origem, da sua illicitude.

$\mathrm{O}$ direito não pode dar validade ao acto juridico, como ensina BEvilaQuA, se o seu objecto fôr of fensivo da moral ou das leis de ordem publica. Conhecendo de doações desta natureza e uma vez impugnada a sua validade, o julgador, ex-vi do disposto no art. $146 \S$ unico do Cod. Civil, deve annullar o acto juridico.

Digam melhor os doutos, mas não me parece outra a solução em face da lei positiva e dos principios juridicos reguladores da materia. 